\title{
Ege Üniversitesi Hastanesi veri tabanında kayıtlı erişkin Hodgkin lenfoma olgularının epidemiyolojik ve genel sağ kalım özelliklerinin retrospektif olarak değerlendirilmesi
}

Retrospective evaluation of the epidemiological and overall survival characteristics of adult Hodgkin lymphoma cases registered to Ege University Hospital database

\author{
Derya Demir ${ }^{10} \quad$ Mine Hekimgil ${ }^{1}$ (D) Emre Demir ${ }^{2}$ (D) Hale Bülbül ${ }^{3}$ (D) \\ Yusuf Ulusoy ${ }^{3}$ (D) Nur Akad Soyer ${ }^{3}$ (D) Yavuz Anacak ${ }^{4}$ (D) Güray Saydam ${ }^{3}$ (D) \\ Fahri Şahin ${ }^{3}$ Nazan Özsan ${ }^{1}$ \\ ${ }^{1}$ Ege Üniversitesi Tıp Fakültesi Tıbbi Patoloji Anabilim Dalı, İzmir, Türkiye \\ ${ }^{2}$ Ege Üniversitesi Tıp Fakültesi Kardiyoloji Anabilim Dalı, İzmir, Türkiye \\ ${ }^{3}$ Ege Üniversitesi Tıp Fakültesi Hematoloji Bilim Dalı, İzmir, Türkiye \\ ${ }^{4}$ Ege Üniversitesi Tıp Fakültesi Radyasyon Onkolojisi Anabilim Dalı, İzmir, Türkiye
}

Öz

Amaç: Hodgkin lenfoma $(\mathrm{HL})$ sıklığı ve mortalite oranları tüm dünyada değişkenlik göstermektedir. Bu çalışmada, HL olgularının epidemiyolojik ve genel sağ kalım analizlerinin, global sonuçlarla karşılaştırılarak değerlendirilmesi amaçlanmıştır.

Gereç ve Yöntem: Ege Üniversitesi Kanserle Savaş Araştırma ve Uygulama Merkezi veri tabanına kayıtlı, 1992-2017 yıllarında HL tanısı alan 972 erişkin olgu retrospektif olarak değerlendirilmiş, CANREG-4 ile kaydedilen veriler SPSS'e aktarılmıştır.

Bulgular: Olguların \%59,9'u erkek olup, ortalama tanı yaşı 41,8 ve medyan tanı yaşı 39 idi. Olguların $\% 94,4$ 'ü klasik Hodgkin lenfoma (KHL) tanısı aldı. Alt tiplerine baktığımızda \%42,1 nodüler sklerozan (NS)-KHL, \%31,0 mikst sellüler (MS)-KHL, \%5,2 lenfositten zengin (LZ)-KHL, \%2,9 lenfositten fakir (LF)-KHL olarak değerlendirildi. Erkeklerde kadınlara göre anlamlı yüksekti. Noduler lenfosit predominant $\mathrm{HL}$ olgularının tamamı EBV negatif iken; KHL olgularının \%52,7'si pozitifti $(p<0,0001)$. Ayrıca \%59 lokalize, \%16,4 bölgesel, \%24,7 yaygın hastalık oluşturmaktaydı. Sağ kalım analizleri bilinen 971 olgunun sağkalımı 1 yıllık \%92, 5 yıllık \%81, 10 yıllık \%70, 15 yıllık \%62, 25 yıllık \%43 idi. Kemik iliği lokalizasyonundan tanı alan olguların sağ kalımının kısa olduğu saptandı $(p<0,0001)$.

Sonuç: HL, en sık görülen ikinci lenfoma tipi olup, erkeklerde kadınlara göre daha sık karşımıza çıkmaktadır. NSKHL en sık görülen alt tip olmakla birlikte, gelişmiş ülkelere göre biraz daha az görüldüğü, MSKHL ve LFKHL alt tiplerinin ise daha ön plana çıktığı dikkatimizi çekmektedir. Ayrıca olgularımızda EBV görülme oranları, gelişmiş ülkelere kıyaslandığında fazla olup, Asya ve Latin Amerika'ya göre daha düşüktür. Erkeklerde, kemik iliği tutulumu olanlarda ve yaygın hastalık oluşturanlarda sağ kalım daha kısa bulunmuştur. Prognostik açıdan, cinsiyet ve hastalık evresi bizim çalışmamızda da öne çıkan önemli parametreler arasında saptanmıştır.

Anahtar Sözcükler: Hodgkin lenfoma, EBV, epidemiyoloji, insidans, sağ kalım.

\begin{abstract}
Aim: Hodgkin lymphoma (HL) shows different incidence and mortality rates all over the world. The aim of this study was to evaluate the epidemiological and overall survival analysis of $H L$ patients and compare them with global findings.
\end{abstract}

Sorumlu yazar: Derya Demir

Ege Üniversitesi Tıp Fakültesi Tıbbi Patoloji Anabilim Dalı,

İmir, Türkiye

E-posta:dr.derya.demir@gmail.com 
Materials and Methods: The data of HL, including 972 adult patients diagnosed within 1992-2017 and recorded at Ege University Cancer Control and Research Center by CANREG-4 program, were evaluated retrospectively with SPSS.

Results: $59.9 \%$ of the patients were male; the mean age was 41.8 , and the median age was 39 . Of all the patients, $94.4 \%$ were diagnosed as $\mathrm{CHL}$. The subtypes of $\mathrm{CHL}$ were evaluated as $42.1 \%$ nodular sclerosis (NS)-CHL, 31.0\% mixed cellular (MC)-CHL, 5.2\% lymphocyte-rich (LR)-CHL, $2.9 \%$ lymphocyte-depleted (LD)-CHL. The disease was significantly predominant in males. While EBV was negative in all nodular lymphocyte predominant Hodgkin lymphoma patients, $52.7 \%$ of CHL patients were positive with EBV $(p<0.0001)$. Also, $59 \%$ of the patients had localized, $16.4 \%$ regional, $24.7 \%$ disseminated disease. Overall survival rates for 1, 5, 10, 15, 25-year were 92\%, 81\%, 70\%, 62\%, 43\% respectively. The patients those had been diagnosed with the bone marrow biopsy had been detected to have poor prognosis $(p<0.0001)$.

Conclusion: In our study, $H L$ is the second most common lymphoma type; the incidence is more common in males than females. Although among our patients NSCHL is the most common subtype of $\mathrm{CH}$, it has a bit less percentage than developed countries, MCCHL and LDCHL subtypes are also prominent in our country. Also, our EBV incidence is higher compared with developed countries but lower than in Asia and Latin America. Overall survival is found lower in patients with male gender, bone marrow involvement, and disseminated disease. Gender and stage of the disease were found to be among the most important prognostic parameters in our study.

Keywords: Hodgkin lymphoma, EBV, epidemiology, incidence, survival.

\section{Giriş}

Hodgkin lenfomalar $(\mathrm{HL})$ sıklıkla lenf nodüllerini tutan, lenfoid hücrelerden köken alan neoplazilerdir. Tümörün morfolojik ve immunfenotipik özellikleri yanı sıra mikroçevresine göre "nodüler lenfosit predominant Hodgkin lenfoma (NLPHL)" ve "klasik Hodgkin lenfoma (KHL)" olmak üzere iki büyük grup tanımlanmıştır. KHL'lar tüm $\mathrm{HL}^{\prime} ı$ n yaklaşık \%90'ını oluşturur. Nodüler sklerozan klasik Hodgkin lenfoma (NSKHL), lenfositten zengin klasik Hodgkin lenfoma (LZKHL), mikst sellüler klasik Hodgkin lenfoma (MSKHL) ve lenfositten fakir klasik Hodgkin lenfoma (LFKHL) olmak üzere dörde ayrılır(1). Onbeş-35 yaşları arasında ve hayatın ileri döneminde olmak üzere iki kez pik yapar $(1,2)$. Hastalığın gelişiminden sorumlu risk faktörleri tartışmalı olmakla birlikte, ailesel faktörler, viral maruziyet ve immun supresyon ile ilişkili olduğu gösterilmiştir (3). EBV enfeksiyonu bu hastalığın patogenezinde önemli rol oynar $(2,4)$. Özellikle mikst sellüler ve lenfositten fakir $\mathrm{KHL}$ alt tiplerinde karşımıza çıkar. Olguların \%98'inden fazlasında germinal merkezden köken alan matür $\mathrm{B}$ hücrelerinden gelişir ve klonal immunglobulin gen yeniden düzenlenimi gösterir. KHL alt tipleri, morfolojik görünümleri yanı sıra klinik özellikleri, risk faktörleri ve EBV ilişkisi açısından birbirinden ayrılır. Gelişmekte olan ülkelerde ve tropikal bölgelerde EBV görülme oranı belirgin artış gösterir $(1,4)$.
Bu çalışmada, Ege Üniversitesi Tıp Fakültesi Hastanesi (EÜTFH) veri tabanına kayıtlı, 19922017 yıllarında Hodgkin lenfoma tanısı alan ve tedavisi yapılan 972 erişkin olgunun epidemiyolojik ve genel sağ kalım analizlerinin yapılması, global sonuçlarla karşılaştırılarak değerlendirilmesi amaçlanmıştır.

\section{Gereç ve Yöntem}

EÜ Kanserle Savaş Araştırma ve Uygulama Merkezi (EÜKAM)'nin özel eğitimli ve sertifikalı kanser kayıt elemanları tarafından 1992-2017 yıllarında, EÜTFH'de 1.293 Hodgkin lenfoma tanısı alan hasta kaydı yapılmıştır. Çocuk hastalar (18 yaş altı) pediatri grubunda ele alınacağı için bu çalışmadan dışlanarak, 972 erişkin HL hastası çalışmaya dahil edilmiştir. $\mathrm{Bu}$ hastalar hastanemizde tanı ve/veya tedavi almışlardır. Sınıflandırmalarda ve sağ kalım analizlerinde DSÖ ve SEER (Surveillance, Epidemiology, and End Results) verileri göz önüne alınarak gruplandırılmış; tümörün histolojik tipi, tanı yaşı, cinsiyet, tümör yerleşim yeri, EBV varlığı, kemik iliği tutulumu, yayılımı, tedavisi ve sağ kalım analizleri açısından değerlendirilmiştir (1). Tümörün histolojik tipi açısından, $\mathrm{KHL}$ ve NLPHL olmak üzere ikiye, KHL'da NSKHL, MSKHL, LZKHL ve LFKHL olarak dört alt tipe ayrımıştır (1). EBV varlığı açısından hastanemizde histopatolojik doku örneklerinde çalışılan kromojenik in situ hibridizasyon ile EBER incelemesi ve /veya immunohistokimyasal 
olarak EBV-LMP1 boyamaları ile değerlendirilmiş; EBV pozitif ve negatif olmak üzere iki gruba ayrımıştır. Kemik iliği tutulumu açısından hastanemizde tanı almış ve KI (kemik iliği) biyopsisi yapılmış hastalar değerlendirilmiştir. CANREG 4 programı ile kaydedilen veriler SPSS (23.0 versiyonu) programına aktarılmıştır. İstatistiksel analizlerde Ki-kare, doğrusal modellemeler, student T-test, Mann Whitney-U, Fischer-exact test ve KaplanMeier sağ kalım analizi yanı sıra Log-rank, cox regresyon analizi uygulanmış, $p<0,05$ değeri anlamlı kabul edilmiştir. Bu çalışma için, Ege Üniversitesi Tıbbi Araştırmalar Etik Kurulundan onay alınmıştır.

\section{Bulgular}

1992-2017 yıllarında Ege Üniversitesi Hastanesi veri tabanında kayıtlı 117.139 hastanın, 6.130'u lenfoma tanısı almıştır. Lenfoma tanısı alan olgular, hastanemiz veri tabanında kayıtlı tüm olguların yaklaşık \%5'ini oluşturmaktadır. $\mathrm{HL}$ ise lenfoma tanısı alan olguların yaklaşık \%21'ini ve tüm malignitelerin ise $\% 1,1$ 'ini oluşturmaktadır.

\section{Hodgkin Lenfomada Epidemiyolojik ve Histopatolojik Özellikler}

HL tanısı alan toplam 1.293 hasta olup, 972'si erişkin (18 yaş ve üzeri) olgulardır. Olguların \%59,9'u (n:582) erkek, \%40,1'i (n:390) kadın olup; ortalama tanı yaşı $41,8( \pm 15,99)$, medyan tanı yaşı ise 39 (aralık:18-89) idi. Histolojik tiplerine baktığımızda, $918(\% 94,4)$ olgu KHL, 54 $(\% 5,6)$ olgu NLPHL tanısı aldı. KHL alt tiplerine baktığımızda ise olguların 409'u (\%42,1) NSKHL, 301'i (\%31) MSKHL, 51'i $(\% 5,2)$ LZKHL, 28'i $(\% 2,9)$ LFKHL tanısı alırken, 129'u $(\% 13,3) \mathrm{KHL}$,
NOS olarak sınıflandırıldı. KHL (n:918) olgularının 546'sı erkek, 372'si kadın olup; erkek kadın oranı 1,5 ve ortalama yaş $41,63 \pm 16,09$ (aralık:18-89) idi. Olguların histolojik tip ve yaş dağılımları (Tablo-1)'de gösterilmiştir.

NSKHL, kadınlarda erkeklere göre daha fazla ve LFKHL hariç, diğer histolojik tipler de erkeklerde kadınlara göre belirgin yüksekti. Histolojik tiplere göre cinsiyet dağılımı istatistiksel olarak da anlamlı saptandı ( $p<0,0001)$ (Şekil-1).

Histopatolojik doku örneklerinde çalışılan EBV sonucu değerlendirilmiş 508 olgunun, 261'i $(\% 51,4)$ EBV pozitif, 247'si ise $(\% 48,7)$ EBV negatif saptandı. Histolojik tiplere baktığımızda, NLPHL olgularının (n:39) tamamı EBV negatif iken; KHL olgularının (n:469) 222'si (\%47,3) negatif, 247'si $(\% 52,7)$ pozitif idi $(p<0,0001)$. Ayrıca KHL'nin iki büyük grubu olan NSKHL ve MSKHL EBV ilişkisi açısından karşılaştırıldı ve aradaki fark istatistiksel olarak anlamlı bulundu $(p<0,0001)$. Histolojik tiplere göre EBV dağılımı ayrıntılı olarak değerlendirilmiştir (Şekil-2).

Patoloji raporlarına göre tanı aldığı yerleşim yeri bilinen 707 olgunun 402'si $(\% 56,9)$ servikal LN, 67 'si $(\% 9,5)$ aksiller LN, 59'u $(\% 8,3)$ inguinal LN, 16 'sı $(\% 2,3)$ intraabdominal LN, 13'ü $(\% 1,8)$ intratorasik LN, 40'। $(\% 5,7)$ lokalizasyonu bilinmeyen LN, 31'i $(\% 4,4)$ multiple LN, 61'i $(\% 8,6)$ ekstranodal ve 18 'i $(\% 2,5) \quad \mathrm{KI}$ yerleşiminden tanı aldı. NLPHL olgularında intratorasik LN, ekstranodal lokalizasyon ve KI yerleşiminden tanı alan olgu saptanmadı. Intraabdominal yerleşimde ise sadece bir olgu bulunmaktaydı. Histolojik tip ve yerleşim yeri dağılımı (Tablo-2)'de gösterilmiştir.

Tablo-1. Olguların histolojik tip-yaş dağılımları.

\begin{tabular}{llllllll}
\hline & NLPHL & KHL, NOS & NSKHL & MSKHL & LZKHL & LFKHL & Toplam \\
\hline \multirow{2}{*}{ Ortanca yaş } & $\mathbf{4 2 , 5}$ & $\mathbf{4 4}$ & $\mathbf{3 3}$ & $\mathbf{4 4}$ & $\mathbf{4 1}$ & $\mathbf{4 9 , 5}$ & $\mathbf{3 9}$ \\
& $\mathbf{( 2 1 - 7 6 )}$ & $\mathbf{( 1 9 - 8 3 )}$ & $\mathbf{( 1 8 - 8 7 )}$ & $\mathbf{( 1 8 - 8 9 )}$ & $\mathbf{( 1 8 - 6 6 )}$ & $\mathbf{( 2 1 - 8 3 )}$ & $\mathbf{( 1 8 - 8 9 )}$ \\
Ortalama & $\mathbf{4 4 , 5 6 \pm}$ & $\mathbf{4 5 , 6 \pm}$ & $\mathbf{3 7 , 1 5} \pm$ & $\mathbf{4 5 , 0 5 \pm}$ & $\mathbf{4 2 , 8} \pm$ & $\mathbf{4 9 , 8 9 \pm}$ & $\mathbf{4 1 , 8 \pm}$ \\
yaş & 14,20 & 16,22 & 15,16 & 16,15 & 12,10 & 17,85 & 15,99 \\
Toplam olgu & $\mathbf{5 4}$ & $\mathbf{1 2 9}$ & $\mathbf{4 0 9}$ & $\mathbf{3 0 1}$ & $\mathbf{5 1}$ & $\mathbf{2 8}$ & $\mathbf{9 7 2}$ \\
\hline
\end{tabular}

Kısaltmalar: NLPHL: Nodüler lenfosit predominant Hodgkin lenfoma, KHL, NOS: Klasik Hodgkin lenfoma, spesifiye edilemeyen, NSKHL: Nodüler sklerozan klasik Hodgkin lenfoma, MSKHL: Mikst sellüler klasik Hodgkin lenfoma, LZKHL: Lenfositten zengin klasik Hodgkin lenfoma, LFKHL: Lenfositten fakir klasik Hodgkin lenfoma. 
Histolojik tiplere göre cinsiyet dağılımı

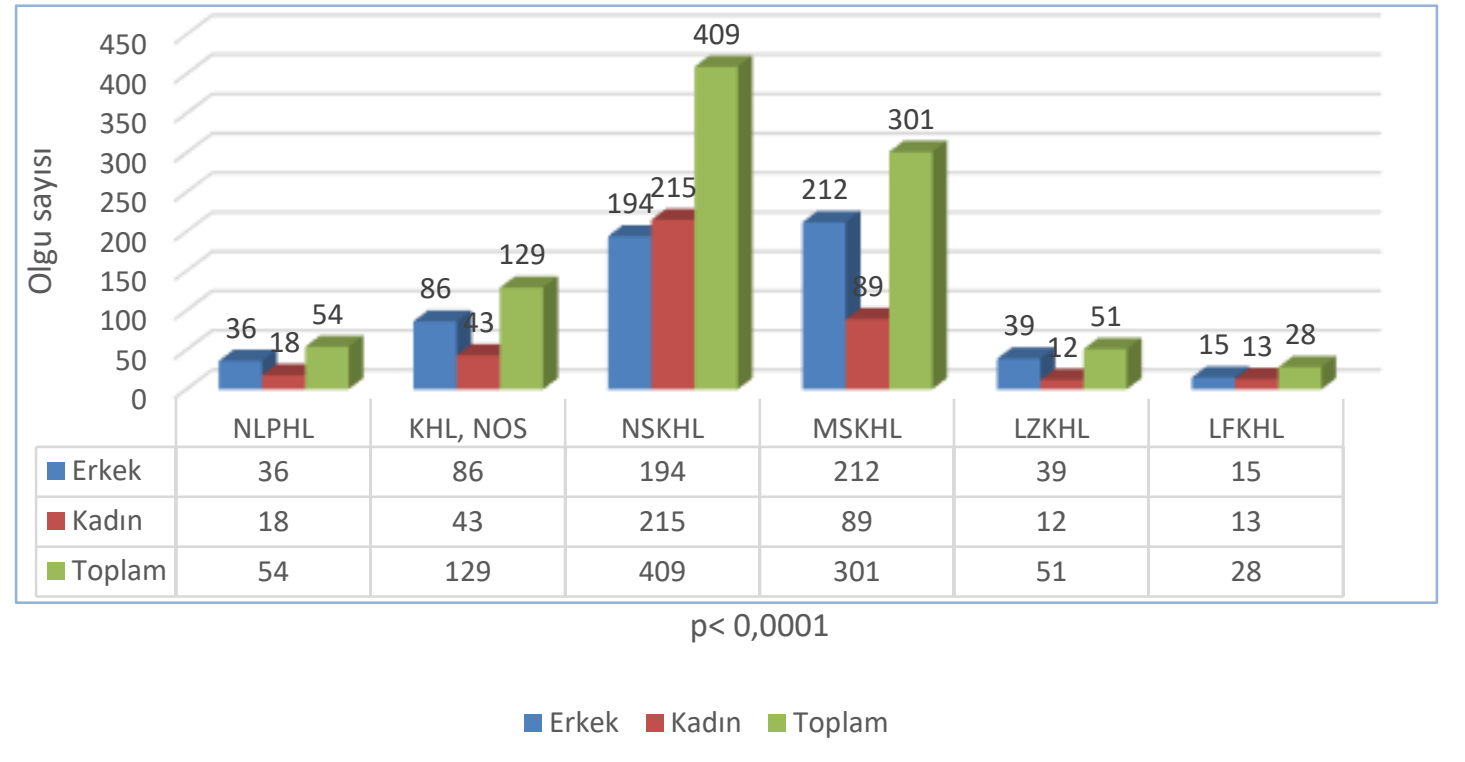

Şekil-1. Histolojik tiplere göre cinsiyet dağılımı.

Kısaltmalar: NLPHL: Nodüler lenfosit predominant Hodgkin lenfoma, KHL, NOS: Klasik Hodgkin lenfoma, spesifiye edilemeyen, NSKHL: Nodüler sklerozan klasik Hodgkin lenfoma, MSKHL: Mikst sellüler klasik Hodgkin lenfoma, LZKHL: Lenfositten zengin klasik Hodgkin lenfoma, LFKHL: Lenfositten fakir klasik Hodgkin lenfoma.

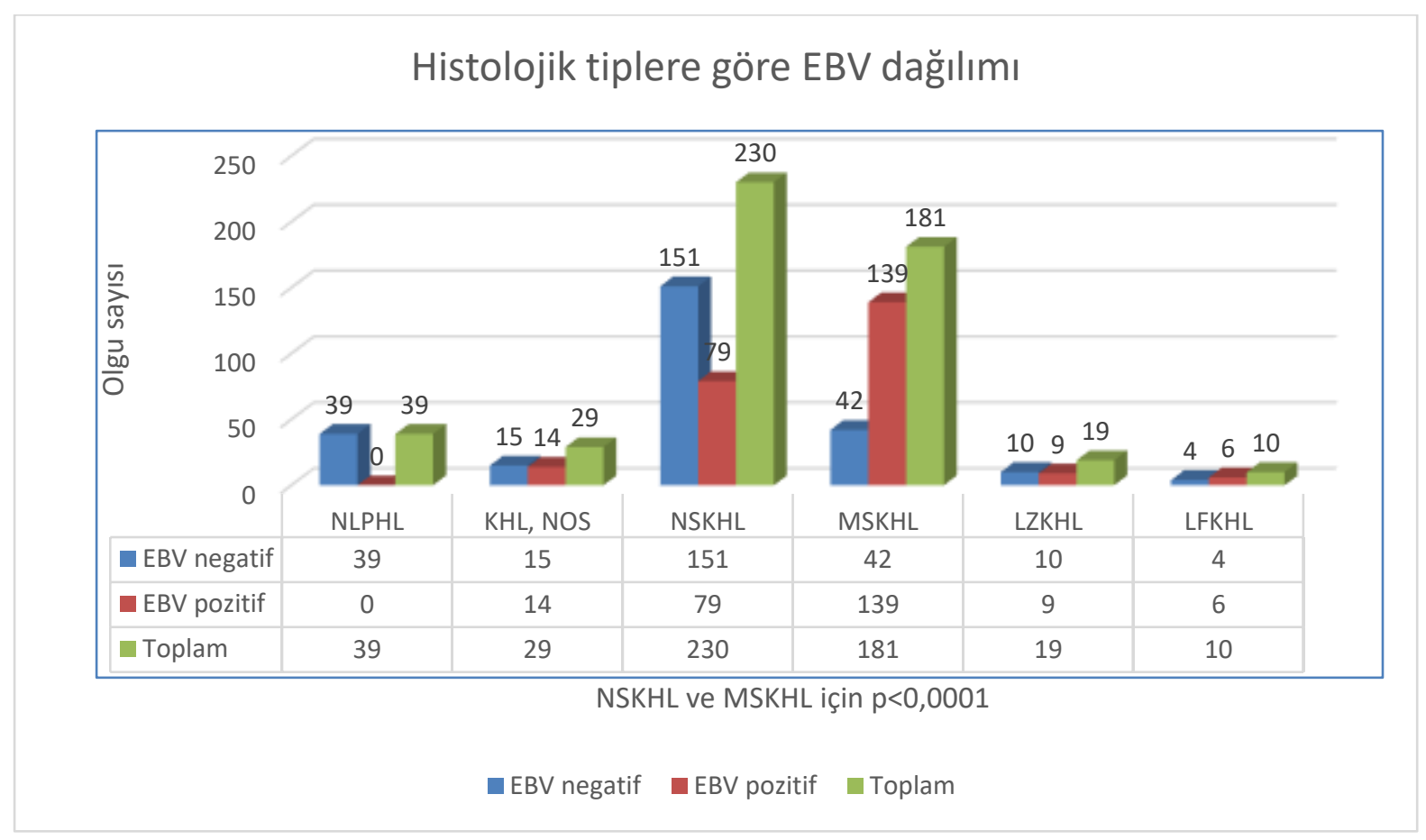

Şekil-2. Histolojik tiplere göre EBV dağılımı.

Kısaltmalar: NLPHL: Nodüler lenfosit predominant Hodgkin lenfoma, KHL, NOS: Klasik Hodgkin lenfoma, spesifiye edilemeyen, NSKHL: Nodüler sklerozan klasik Hodgkin lenfoma, MSKHL: Mikst sellüler klasik Hodgkin lenfoma, LZKHL: Lenfositten zengin klasik Hodgkin lenfoma, LFKHL: Lenfositten fakir klasik Hodgkin lenfoma, EBV: Epstein Barr Virus. 
Tablo-2. Olguların histolojik tip-yerleşim yeri dağılımları.

\begin{tabular}{llllllll}
\hline & NLPHL & KHL, NOS & NSKHL & MSKHL & LZKHL & LFKHL & Toplam \\
\hline LN, & 4 & 3 & 21 & 9 & 3 & 0 & 40 \\
lokalizasyonu & $(\% 7,55)$ & $(\% 5,77)$ & $(\% 6,67)$ & $(\% 3,72)$ & $(\% 10,34)$ & $(\% 0)$ & $(\% 5,7)$ \\
bilinmeyen & 26 & 9 & 183 & 162 & 17 & 5 & 402 \\
Servikal LN & $(\% 49,06)$ & $(\% 17,30)$ & $(\% 58,1)$ & $(\% 66,94)$ & $(\% 58,62)$ & $(\% 31,25)$ & $(\% 56,9)$ \\
& 8 & 2 & 16 & 28 & 3 & 2 & 59 \\
Inguinal LN & $(\% 15,09)$ & $(\% 3,85)$ & $(\% 5,08)$ & $(\% 11,57)$ & $(\% 10,34)$ & $(\% 12,5)$ & $(\% 8,3)$ \\
& 11 & 0 & 34 & 18 & 2 & 2 & 67 \\
Aksiller LN & $(\% 20,75)$ & $(\% 0)$ & $(\% 10,79)$ & $(\% 7,44)$ & $(\% 6,9)$ & $(\% 12,5)$ & $(\% 9,5)$ \\
Intraabdominal & 1 & 2 & 4 & 6 & 0 & 3 & 16 \\
LN & $(\% 1,89)$ & $(\% 3,85)$ & $(\% 1,27)$ & $(\% 2,48)$ & $(\% 0)$ & $(\% 18,75)$ & $(\% 2,3)$ \\
Intratorasik LN & 0 & 2 & 6 & 5 & 0 & 0 & 13 \\
& $(\% 0)$ & $(\% 3,85)$ & $(\% 1,9)$ & $(\% 2,07)$ & $(\% 0)$ & $(\% 0)$ & $(\% 1,8)$ \\
Multiple LN & 3 & 2 & 17 & 6 & 1 & 2 & 31 \\
& $(\% 5,66)$ & $(\% 3,85)$ & $(\% 5,4)$ & $(\% 2,48)$ & $(\% 3,45)$ & $(\% 12,5)$ & $(\% 4,4)$ \\
Ekstranodal & 0 & 15 & 34 & 8 & 2 & 2 & 61 \\
& $(\% 0)$ & $(\% 28,84)$ & $(\% 10,79)$ & $(\% 3,3)$ & $(\% 6,9)$ & $(\% 12,5)$ & $(\% 8,6)$ \\
Kemik iliği & 0 & 17 & 0 & 0 & 1 & 0 & 18 \\
& $(\% 0)$ & $(\% 32,69)$ & $(\% 0)$ & $(\% 0)$ & $(\% 3,45)$ & $(\% 0)$ & $(\% 2,5)$ \\
Toplam & 53 & 52 & 315 & 242 & 29 & 16 & 707 \\
& $(\% 100)$ & $(\% 100)$ & $(\% 100)$ & $(\% 100)$ & $(\% 100)$ & $(\% 100)$ & $(\% 100)$ \\
\hline
\end{tabular}

Kısaltmalar: NLPHL: Nodüler lenfosit predominant Hodgkin lenfoma, KHL, NOS: Klasik Hodgkin lenfoma, spesifiye edilemeyen, NSKHL: Nodüler sklerozan klasik Hodgkin lenfoma, MSKHL: Mikst sellüler klasik Hodgkin lenfoma, LZKHL: Lenfositten zengin klasik Hodgkin lenfoma, LFKHL: Lenfositten fakir klasik Hodgkin lenfoma, LN: Lenf nodülü.

Tablo-3. Histolojik tiplere göre hastalığın yaygınlığı.

\begin{tabular}{llll}
\hline & NLPHL & KHL & Toplam \\
\hline Lokalize & 29 & 399 & 428 \\
& $(\% 78,38)$ & $(\% 57,9)$ & $(\% 59)$ \\
Bölgesel & 2 & 117 & 119 \\
Yaygın & $(\% 5,4)$ & $(\% 17)$ & $(\% 16,4)$ \\
& 6 & 173 & 179 \\
Toplam & $(\% 16,22)$ & $(\% 25,1)$ & $(\% 24,7)$ \\
P=0,039 & 37 & 689 & 726 \\
\end{tabular}

Ayrıca $972 \mathrm{HL}$ hastasının topografi kodu dağılımlarına baktığımızda; C07.9 parotis 1 $(\% 0,1)$, C09.9 tonsil, BBT $5(\% 0,5)$, C11.9 nazofarinks, BBT $6(\% 0,6)$, C16.9 mide, BBT 2 $(\% 0,2)$, C17.9 ince barsak, BBT $1(\% 0,1)$, C22.0 karaciğer $6(\% 0,6)$, C34,9 akciğer, BBT $7(\% 0,7)$, C38,1 ön mediasten 24 (\%2,5), C41,2 omurga/vertebra $2(\% 0,2)$, C42.2 dalak $1(\% 0,1)$, C49.0 baş, yüz, boyun yumuşak dokular 2 $(\% 0,2)$, C50.9 meme, BBT $1(\% 0,1)$, C77.0 baş, yüz, boyun lenf düğümü $419(\% 43,1), \quad$ C77.1 göğüs içi/intratorasik lenf düğümü $22(\% 2,3)$, C77.2 karın içi/intraabdominal lenf düğümü 22 $(\% 2,3), C 77.3$ aksilla ya da kol lenf düğümü 64 $(\% 6,6), \quad C 77.4$ inguinal bölge ve bacak lenf düğümü $52(\% 5,3), C 77.5$ pelvik lenf düğümleri 2 $(\% 0,2), C 77.8$ multiple alanların lenf düğümleri 209 (\%21,5), C77.9 lenf düğümü, BBT 103
$(\% 10,6)$, C80.9 primer yeri bilinmeyen $2(\% 0,2)$ olgu olduğu görüldü.

599 olguda evreleme amacıyla Ki biyopsisi yapılmış olup, $529(\% 88,3)$ olguda Kİ tutulumu izlenmez iken, $70(\% 11,7)$ olguda Ki tutulumu saptandı. NLPHL olgularının (n:36) hiçbirinde KI tutulumu gözlenmedi. KHL ( $\mathrm{n}: 563)$ olgularının \%12,4' ünde (n:70) Ki tutulumu saptandı (Şekil-3).

Hastalığın yaygınlığına baktığımızda; 726 olgunun 428'i (\%59) lokalize, 119 (\%16,4) bölgesel, $179(\% 24,7)$ yaygın hastalık oluşturmaktaydı. NLPHL ve KHL arasındaki fark istatistiksel olarak da anlamlıydı $(p=0,039)$ (Tablo-3). Hastalığın yaygınlığının histolojik tiplere göre dağılımı (Şekil-4)'te verilmiştir.

907 olgunun 733'ü $(\% 80,8)$ merkezimizde tedavi alırken, $174(\% 19,2)$ olgu tedaviyi kabul etmedi. Tedavi almayan 174 olgunun 19'u daha indolan seyirli NLPHL, 155'i KHL grubunda idi (Şekil-5). 


\section{Histolojik tiplere göre kemik iliği tutulumu}

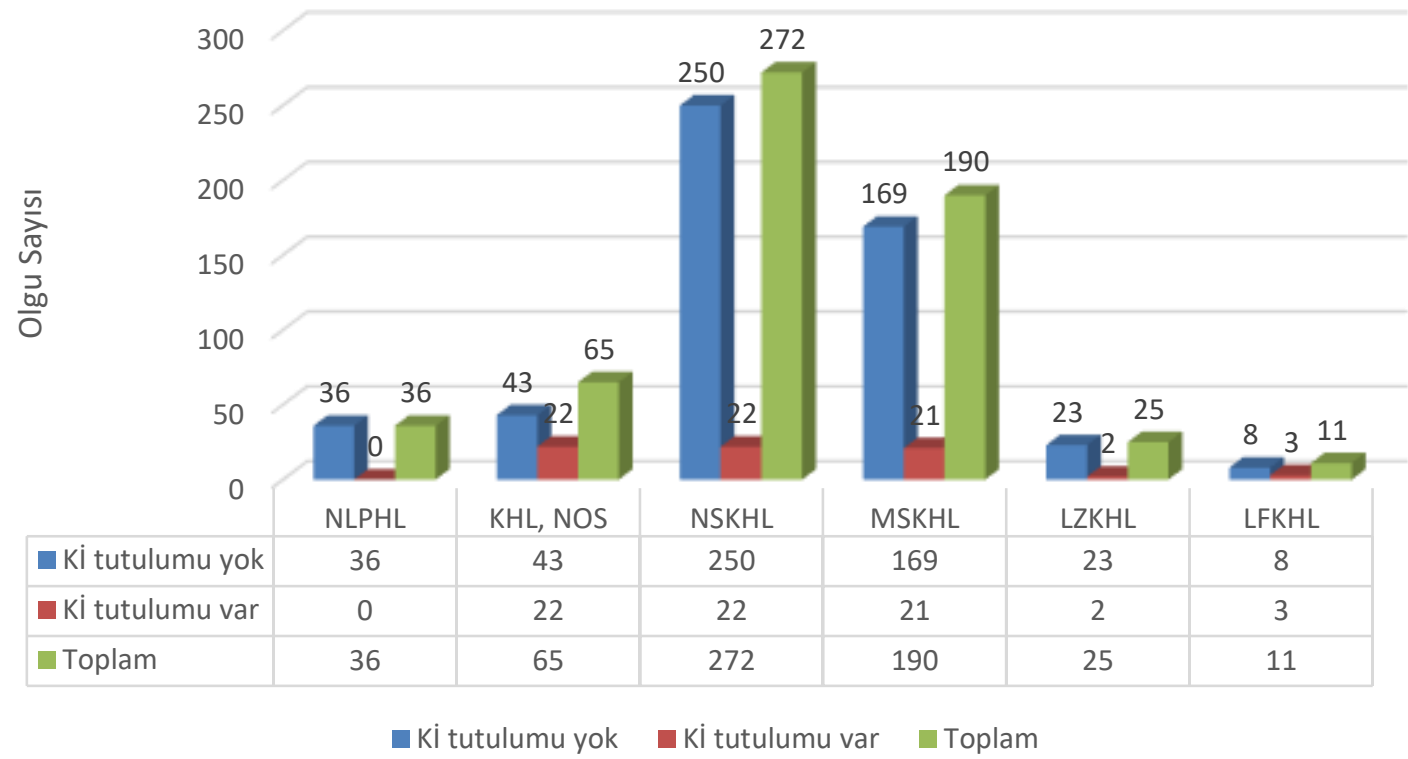

Şekil-3. Histolojik tiplere göre kemik iliği tutulumu.

Kısaltmalar: NLPHL: Nodüler lenfosit predominant Hodgkin lenfoma, KHL, NOS: Klasik Hodgkin lenfoma, spesifiye edilemeyen, NSKHL: Nodüler sklerozan klasik Hodgkin lenfoma, MSKHL: Mikst sellüler klasik Hodgkin lenfoma, LZKHL: Lenfositten zengin klasik Hodgkin lenfoma, LFKHL: Lenfositten fakir klasik Hodgkin lenfoma, Ki: Kemik iliği.

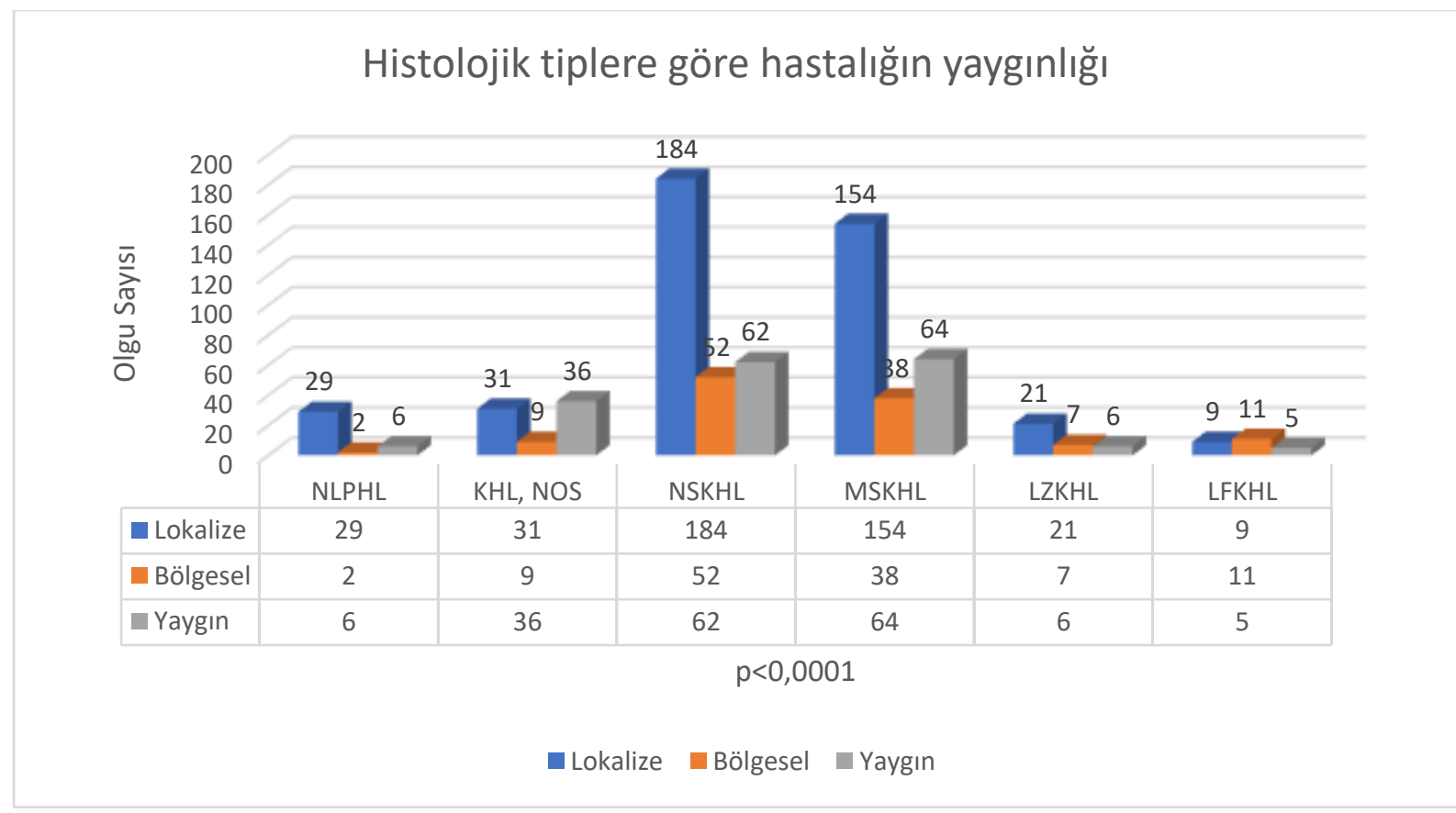

Şekil-4. Histolojik tiplere göre hastalığın yaygınlığı.

Kısaltmalar: NLPHL: Nodüler lenfosit predominant Hodgkin lenfoma, KHL, NOS: Klasik Hodgkin lenfoma, spesifiye edilemeyen, NSKHL: Nodüler sklerozan klasik Hodgkin lenfoma, MSKHL: Mikst sellüler klasik Hodgkin lenfoma, LZKHL: Lenfositten zengin klasik Hodgkin lenfoma, LFKHL: Lenfositten fakir klasik Hodgkin lenfoma. 


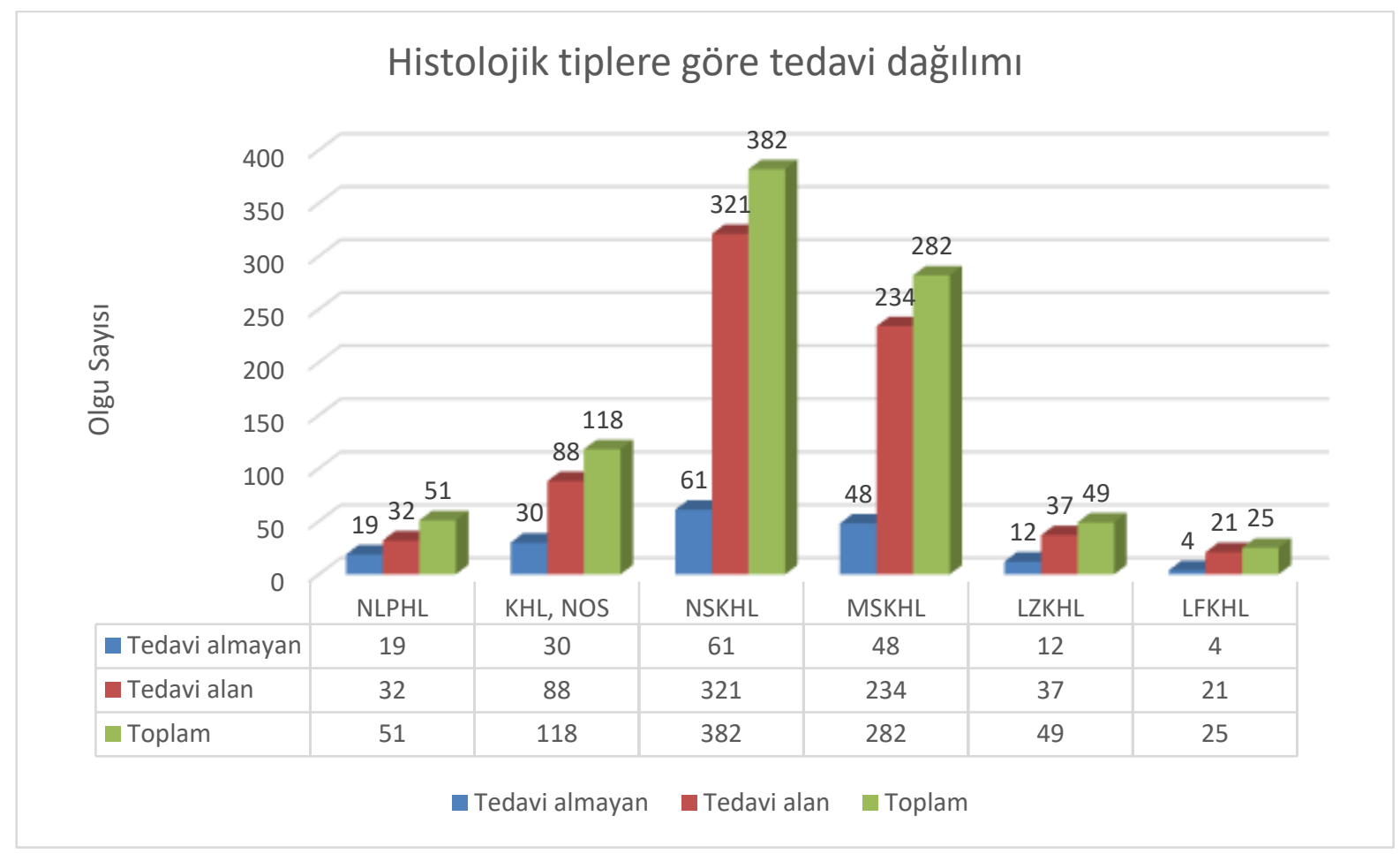

Şekil-5. Histolojik tiplere göre tedavi dağılımı.

Kısaltmalar: NLPHL: Nodüler lenfosit predominant Hodgkin lenfoma, KHL, NOS: Klasik Hodgkin lenfoma, spesifiye edilemeyen, NSKHL: Nodüler sklerozan klasik Hodgkin lenfoma, MSKHL: Mikst sellüler klasik Hodgkin lenfoma, LZKHL: Lenfositten zengin klasik Hodgkin lenfoma, LFKHL: Lenfositten fakir klasik Hodgkin lenfoma.

Tedavi ayrıntısına baktığımızda; 923 olgunun 694'ü $(\% 75,2)$ KT alır iken, 229'u $(\% 24,8)$ KT almadı. Histolojik tiplere göre, $50 \mathrm{NLPHL}$ olgusunun ise 28 'i, $873 \mathrm{KHL}$ olgusunun 666 '। KT aldı $(p<0,0001)$. HL'da tedavi seçeneklerinden bir tanesi olan RT oranlarına baktığımızda; 924 olgunun 105 'i $(\% 11,4)$ RT alırken, 819'u $(\% 88,6)$ RT almadı. Ayrıca 51 NLPHL olgusunun dördü RT aldı. Bunların dışında 931 olgumuzun 13'ü $(\% 1,4)$ immunoterapi alır iken, 51 NLPHL olgumuzun hiçbiri immunoterapi almadı.

\section{Hodgkin Lenfomada Sağ Kalım Özellikleri}

Sağ kalım analizleri bilinen 971 olgunun 1 yıllık sağ kalımı \%92, 5 yıllık sağ kalım \%81, 7 yıllık sağ kalım $\% 77,10$ yıllık sağ kalım $\% 70,15$ yıllık sağ kalım \%62, 20 yıllık sağ kalım \%55, 25 yıllık sağ kalım \%43 tür. Medyan sağ kalım 302 ay (\%95 güven aralığı 231,6-302,0) olarak bulundu. NLPHL da sağ kalım KHL'ya göre daha iyi olmakla birlikte aradaki fark istatistiksel olarak anlamlı saptanmadı. Sağ kalım verilerinin ayrıntıı olarak değerlendirilmesi (Tablo-4, Tablo-5) ve (Tablo-6)'da verilmiştir.
Kİ lokalizasyonundan tanı alan olguların tamamı $\mathrm{KHL}$ grubunda olup, nodal ve ekstranodal lokalizasyondan tanı alan olgularla kıyaslandığında genel sağ kalımın belirgin kısa olduğu ve istatistiksel olarak da anlamlı olduğu saptandı $(p<0,0001)$. Ancak diğer lokalizasyonlar arasında bir fark bulunmadı.

Beklenildiği gibi tedavi alanlarda sağ kalım, almayanlara göre daha uzun idi ve istatistiksel olarak da anlamlı bulundu $(p<0,0001)$. Tedavi rejimlerine baktığımızda, KT almayanlarda ortalama sağ kalım 181,9 ay, medyan sağ kalım 166 ay (\%95 güven aralığı 128,2-231,5) olup; alanlarda ortalama sağ kalım 231,1 ay, medyan sağ kalım 302 ay (\%95 güven aralığı 281,7$302,0)$ dır. İstatistiksel olarak aradaki fark anlamlı idi $(p<0,0001)$. RT alanlarda sağ kalım, almayanlara göre daha iyi olmakla birlikte, istatistiksel anlamlılık saptanmadı $(p=0,246)$ (Tablo-4). 
Tablo-4. Sağ kalım verilerinin ayrıntılı değerlendirilmesi.

\begin{tabular}{|c|c|c|c|c|c|c|}
\hline & $\begin{array}{l}\text { 1-yıllık } \\
\text { sağ kalım }\end{array}$ & $\begin{array}{l}\text { 5-yıllık } \\
\text { sağ kalım }\end{array}$ & $\begin{array}{l}\text { 10-yıllık } \\
\text { sağ kalım }\end{array}$ & $\begin{array}{l}\text { 15-yıllık } \\
\text { sağ kalım }\end{array}$ & $\begin{array}{l}\text { 20-yıllık } \\
\text { sağ kalım }\end{array}$ & \\
\hline NLPHL & $\% 96$ & $\% 82$ & $\% 72$ & $\% 60$ & & $p>0,05$ \\
\hline KHL & \%92 & $\% 81$ & $\% 71$ & $\% 62$ & $\% 55$ & \\
\hline NSKHL & $\% 95$ & $\% 84$ & $\% 76$ & $\% 68$ & $\% 63$ & $p>0,05$ \\
\hline MSKHL & $\% 92$ & $\% 84$ & $\% 74$ & $\% 66$ & $\% 66$ & \\
\hline LZKHL & $\% 93$ & $\% 82$ & $\% 64$ & $\% 54$ & $\% 40$ & \\
\hline LFKHL & $\% 73$ & $\% 68$ & $\% 68$ & $\% 68$ & $\% 68$ & \\
\hline EBV negatif & \%92 & $\% 85$ & $\% 76$ & $\% 76$ & $\% 76$ & $p>0,05$ \\
\hline EBV pozitif & $\% 89$ & $\% 81$ & $\% 74$ & $\% 52$ & $\% 52$ & \\
\hline Erkek & $\% 91$ & $\% 80$ & $\% 67$ & $\% 55$ & $\% 46$ & $p=0,006$ \\
\hline Kadın & $\% 93$ & $\% 83$ & $\% 76$ & $\% 76$ & $\% 76$ & \\
\hline Kİ negatif & $\% 94$ & $\% 87$ & $\% 79$ & $\% 68$ & & $p<0,0001$ \\
\hline Kİ pozitif & $\% 80$ & $\% 62$ & $\% 52$ & $\% 52$ & & \\
\hline Lokalize & $\% 95$ & $\% 85$ & $\% 79$ & $\% 70$ & & $p<0,0001$ \\
\hline Bölgesel & \%92 & $\% 80$ & $\% 70$ & $\% 67$ & & \\
\hline Yaygın & \%83 & $\% 69$ & $\% 55$ & $\% 46$ & & \\
\hline Tedavi - & $\% 83$ & $\% 67$ & $\% 61$ & $\% 50$ & $\% 50$ & $p<0,0001$ \\
\hline Tedavi + & $\% 94$ & $\% 84$ & $\% 73$ & $\% 65$ & $\% 55$ & \\
\hline KT - & $\% 85$ & $\% 70$ & $\% 60$ & $\% 49$ & $\% 38$ & $p<0,0001$ \\
\hline $\mathbf{K T}+$ & $\% 94$ & $\% 85$ & $\% 74$ & $\% 65$ & $\% 60$ & \\
\hline RT - & $\% 91$ & $\% 81$ & $\% 71$ & $\% 60$ & $\% 53$ & $p=0,246$ \\
\hline RT + & $\% 97$ & $\% 86$ & $\% 71$ & $\% 69$ & $\% 59$ & \\
\hline
\end{tabular}

Kısaltmalar: NLPHL: Nodüler lenfosit predominant Hodgkin lenfoma, KHL: Klasik Hodgkin lenfoma, NSKHL: Nodüler sklerozan klasik Hodgkin lenfoma, MSKHL: Mikst sellüler klasik Hodgkin lenfoma, LZKHL: Lenfositten zengin klasik Hodgkin lenfoma, LFKHL: Lenfositten fakir klasik Hodgkin lenfoma, EBV: Epstein Barr Virus, Ki: Kemik iliği, KT: Kemoterapi, RT: Radyoterapi.

Tablo-5. Sağ kalım verilerinin histolojik tip, cinsiyet ve EBV ilişkisi açısından değerlendirilmesi.

\begin{tabular}{|c|c|c|c|c|c|c|}
\hline & $\begin{array}{l}\text { 1-yıllık } \\
\text { sağ kalım }\end{array}$ & $\begin{array}{l}\text { 5-yıllık } \\
\text { sağ kalım }\end{array}$ & $\begin{array}{l}\text { 10-yıllık } \\
\text { sağ kalım }\end{array}$ & $\begin{array}{l}\text { 15-yıllık } \\
\text { sağ kalım }\end{array}$ & $\begin{array}{l}20 \text { 2-yıllık } \\
\text { sağ kalım }\end{array}$ & \\
\hline \multicolumn{7}{|l|}{$\underline{N L P H L}$} \\
\hline Erkek & $\% 97$ & $\% 87$ & $\% 77$ & & & $\mathrm{p}=0,472$ \\
\hline Kadın & $\% 94$ & $\% 71$ & $\% 62$ & $\% 62$ & & \\
\hline \multicolumn{7}{|l|}{$\underline{K H L}$} \\
\hline$\overline{\text { Erkek }}$ & $\% 90$ & $\% 79$ & $\% 67$ & $\% 55$ & $\% 46$ & $p=0,003$ \\
\hline Kadın & $\% 93$ & $\% 84$ & $\% 76$ & $\% 76$ & $\% 76$ & \\
\hline EBV negatif & $\% 92$ & $\% 85$ & $\% 77$ & $\% 77$ & & $p=0,232$ \\
\hline $\begin{array}{l}\text { EBV pozitif } \\
\text { NSKHL }\end{array}$ & $\% 89$ & $\% 81$ & $\% 73$ & $\% 52$ & $\% 52$ & \\
\hline Erkek & $\% 95$ & $\% 79$ & $\% 65$ & $\% 55$ & $\% 48$ & $p=0,001$ \\
\hline Kadın & $\% 95$ & $\% 89$ & $\% 83$ & $\% 83$ & $\% 83$ & \\
\hline EBV negatif & $\% 95$ & $\% 88$ & $\% 83$ & & & $p=0,135$ \\
\hline EBV pozitif & $\% 92$ & $\% 84$ & $\% 73$ & & & \\
\hline \multicolumn{7}{|l|}{ MSKHL } \\
\hline Erkek & $\% 92$ & $\% 84$ & $\% 75$ & $\% 65$ & $\% 65$ & $p=0,758$ \\
\hline Kadın & $\% 91$ & $\% 82$ & $\% 72$ & $\% 72$ & $\% 72$ & \\
\hline EBV negatif & $\% 90$ & $\% 84$ & $\% 70$ & $\% 70$ & & $p=0,968$ \\
\hline EBV pozitif & $\% 90$ & $\% 83$ & $\% 78$ & $\% 62$ & $\% 62$ & \\
\hline
\end{tabular}

Kısaltmalar: NLPHL: Nodüler lenfosit predominant Hodgkin lenfoma, KHL: Klasik Hodgkin lenfoma, NSKHL: Nodüler sklerozan klasik Hodgkin lenfoma, MSKHL: Mikst sellüler klasik Hodgkin lenfoma, EBV: Epstein Barr Virus. 
Tablo-6. Yerleşim yerine göre sağ kalım verilerinin değerlendirilmesi.

\begin{tabular}{|c|c|c|c|c|c|c|}
\hline & $\begin{array}{l}1 \text { yıllık sağ } \\
\text { kalım }\end{array}$ & $\begin{array}{l}5 \text { yıllık sağ } \\
\text { kalım }\end{array}$ & $\begin{array}{l}10 \text { yıllık } \\
\text { sağ kalım }\end{array}$ & $\begin{array}{l}15 \text { yıllık } \\
\text { sağ kalım }\end{array}$ & $\begin{array}{l}20 \quad \text { yıllık } \\
\text { sağ kalım }\end{array}$ & $\begin{array}{l}\text { Ortalama } \\
\text { sağ kalım }\end{array}$ \\
\hline $\begin{array}{l}\text { LN, lokalizasyonu } \\
\text { bilinmeyen }\end{array}$ & $\% 94$ & $\% 79$ & $\% 79$ & $\% 70$ & - & 152,8 ay \\
\hline Servikal LN & $\% 93$ & $\% 87$ & $\% 80$ & $\% 73$ & $\% 73$ & 215,1 ay \\
\hline İnguinal LN & $\% 91$ & $\% 70$ & $\% 67$ & $\% 60$ & $\% 60$ & 200,4 ay \\
\hline Aksiller LN & $\% 95$ & $\% 79$ & $\% 71$ & $\% 66$ & - & 175,7 ay \\
\hline İntraabdominal LN & $\% 91$ & $\% 83$ & $\% 83$ & - & - & 141,1 ay \\
\hline İntratorasik LN & $\% 84$ & $\% 84$ & $\% 47$ & - & - & 127,2 ay \\
\hline Multiple LN & $\% 93$ & $\% 86$ & $\% 65$ & $\% 65$ & - & 152,8 ay \\
\hline Ekstranodal & $\% 76$ & $\% 71$ & $\% 69$ & $\% 55$ & $\% 55$ & 164,5 ay \\
\hline Kemik iliği & $\% 73$ & $\% 48$ & $\% 29$ & $\% 29$ & - & 93,7 ay \\
\hline
\end{tabular}

$\mathrm{p}<0,0001$

Kısaltmalar: LN: Lenf nodülü.

\section{Tartışma}

Hodgkin lenfoma $(\mathrm{HL})$, genellikle genç erişkin dönemde karşımıza çıkan ve tedavi rejimleri ile kür olabilen malign neoplazidir. HL'nın yıllık insidansı, her 100.000 popülasyonda 2,8-3 olgudur(2). Amerika Birleşik Devletleri'nde (ABD), her yıl yaklaşık 8.500 yeni hasta $\mathrm{HL}$ tanısı almaktadır(3,5). Bu sayı lenfoma tanısı alan hastaların \%10'unu oluşturmaktadır $(3,6)$. Bizim merkezimizde ise bu oran \%21'dir. Yayınlara baktığımızda da dünyada en sık görülen ikinci lenfoma tipi olup, görülme oranı \%15-25 arasında değişmektedir (7). Ayrıca ABD'de yeni tanı alan kanser vakalarının yaklaşık \%0,5'ini oluşturmaktadır (6). Bizim serimizde ise tüm kanser vakalarının \%1,1'ini oluşturmaktadır. Literatür ile kıyaslandığında bizim oranlarımızın fazla olmasının nedeni, merkezimizin Ege Bölgesi'nin en büyük hastanesi olması ve ayırıcı tanı açısından zorluklar yaşanabilen bu vakaların, merkezimize yönlendirilmesi ile ilişkili olabilir.

DSÖ'de NLPHL'ler tüm HL'ların yaklaşık $\% 10$ 'unu oluşturur(1). Ancak bazı çalışmalarda $\% 5$ ve altında olduğu bulunmuştur(7-10). Bizim çalışmamızda \%5,6 dolayında saptandı. Çalışmamızda 18 yaş altı olguların olmaması, oranımızın düşük olmasının nedenlerinden biri olabilir, çünkü hayatın 4.-5. dekatında pik yapmasına rağmen, çocukluk yaş grubunda da yaygın olarak karşımıza çıkar $(1,11)$. ABD'de 2000-2014 yılları arasında, 1401 NLPHL verisinin değerlendirildiği çalışmada da ortanca yaş 43 olarak bulunmuş; erkeklerde daha fazla olduğu saptanmıştır (12). Bizim serimizde de ortanca yaş 42,5 ve erkek:kadın oranı 2:1 idi. Ayrıca histolojik tiplere baktığımızda NSKHL'da ortanca yaş 33 olup, literatüre benzer şekilde en küçük yaş dağılımı bu grupta görüldü $(1,11)$. LFKHL'da olgu sayımız çok olmamakla birlikte, ortanca yaş 49,5 idi.

$\mathrm{KHL}$ alt tiplerine baktığımızda; çalışmamızda, \%52 NSKHL, \%38 MSKHL, \%6,5 LZKHL, \%3,5 LFKHL dağılımı ile karakterliydi. Avrupa ve ABD verilerine göre, NSKHL \%70, MSKHL \%20-25, LZKHL \%5, LFKHL <\%1 dolayındadır(1). Memiş ve ark yaptığı ulusal çalışmada erişkin $\mathrm{HL}$ olgularında \%47 NSKHL, \%35 MSKHL, \%12 LZKHL ve $\% 7$ LFKHL dağılımı ile karakterliydi(13). NSKHL, gelişmiş ülkelerde ve kentsel bölgelerde daha sık görülürken, MSKHL ve LFKHL gelişmekte olan ülkelerde ve kırsal bölgelerde daha sıktır. Çalışmamızda MSKHL ve LFKHL'nın gelişmiş ülkelere göre öne çıktığını gördük.

NSKHL hariç, tüm HL'lar erkeklerde daha sıktır $(1,2,9,12)$. Bizim olgularımızın da \%60'ı erkekti. Ayrıca literatüre benzer şekilde, NSKHL kadınlarda erkeklere göre daha fazla saptandı ve LFKHL hariç, diğer histolojik tipler de erkeklerde kadınlara göre belirgin yüksekti. Histolojik tiplere göre cinsiyet dağılımı istatistiksel olarak da anlamlı saptandı $(p<0,0001)$.

Kuzey Amerika ve Avrupa ülkelerinde $\mathrm{HL}$ olgularında EBV görülme oranı \%26-50 arasında değişirken $(14,15)$; NLPHL olguları dışlandığında bu oran \%28-62'lere çıkmaktadır (2). NLPHL'da 
EBV görülme oranı $\% 5$ 'in altındadır. Bizim serimizde EBV görülme oranı KHL'da \%52,7'dir. NLPHL olgularımızın tamamı EBV negatifti $(p<0,0001)$. Literatürde EBV pozitifliği MSKHL'da en yüksek (\%50-70) olup, NSKHL'de ise \%10-42 dolayındadır(2,15). Bizim serimizde MSKHL olgularımızda \%77, NSKHL'da \%34 dolayında olup, aradaki fark istatistiksel olarak anlamdı bulundu $(p<0,0001)$. Çin ve Kore'den bildirilen yayınlarda EBV ilişkili $\mathrm{HL}$ görülme oranları sırasıyla \%61-68 ve \%63-70 dolayındadır $(2,16-$ 18). Ayrıca Latin Amerika ülkelerinde de bu oran \%67-94'lere çıkmaktadır (2,19-21). Gelişmiş ve gelişmekte olan ülkeler arasında EBV görülme oranları farklılık göstermektedir. Gelişmekte olan ülkelerde HL'da EBV pozitifliği daha sıktır ve hastalık daha erken yaşta ortaya çıkmaktadır(14). Bizim serimizde de EBV görülme oranları, gelişmiş ülkelere kıyaslandığında fazladır. Ancak Asya ve Latin Amerika'ya göre de daha düşüktür.

NLPHL çoğunlukla asemptomatik olup, periferik lenf nodüllerinde büyüme ile kendini gösterir. En sık servikal, aksiller ve inguinal lenf nodülleri tutulur(1,3). Bizim serimizde de en sık sırasıyla $\% 49$ servikal, \%21 aksiller ve \%15 inguinal lenf nodülü tutulumu gözlendi. İntratorasik LN, ekstranodüler lokalizasyon ve $\mathrm{KI}$ yerleşiminden tanı alan olgu saptanmadı. KHL'lar en sık servikal lenf nodülü (\%75) olmak üzere mediastinal, aksiller ve paraaortik lokalizasyonlarda gelişir. Çalışmamızda en sık \%57,5 servikal LN olmak üzere sırasıyla $\% 8,5$ aksiller ve $\% 7,8$ inguinal $L N$ tutulumu saptandı. Ayrıca mediastinal lokalizasyondan tanı alan olgularımız (intratorasik-mediastinal lenf nodülü ve mediastinal küçük doku örnekleri) birlikte değerlendirildiğinde oranımız \%6,6 dolayında bulundu. KHL'de primer ekstranodal tutulum nadirdir (1). Bizim çalışmamızda da en sık akciğer olmak üzere sırasıyla karaciğer, nazofarinks, yumuşak doku, tonsil, kemik ve dalak olmak üzere ektranodal lokalizasyondan tanı alan olgularımız \%4,7 dolayında idi. Yang ve ark yaptığı çalışmada en sık akciğer olmak üzere sırasıyla kemik, nazofarinks, parotis, beyin ve adrenal bez olmak üzere primer ekstranodal $\mathrm{HL}$ oranı \%7,4 dolayında bulunmuştur (22). Ayrıca literatürde ki çalışmalara baktığımızda, primer ekstranodal $\mathrm{HL}$ oranı yaklaşık \%5-10 dolayında bildirilmiştir $(23,24)$.

Daha indolan seyirli NLPHL'da KI tutulumu neredeyse hiç beklenmez iken, KHL'da \%5 dolayındadır (1). Ancak bazı çalışmalarda bu oran \%5-15 dolayındadır (25). NLPHL olgularımızın hiçbirinde Kİ tutulumu gözlenmedi. KHL olgularımızın ise \%12,4' ünde KI tutulumu saptandı. KHL alt tiplerine baktığımızda LFKHL'da KI tutulumu en fazla olup, \%27 dolayında bulundu. İkinci sırada, MSKHL'da \%11 dolayında KI tutulumu saptandı. Ancak LFKHL'da az sayıda hasta olduğu için istatistiksel olarak karşılaştırılamadı. Tedavideki ilerlemeler ile histolojik alt tip ve prognostik özellikler arasında belirgin farklar ortadan kalkmış olmasına rağmen, LFKHL daha kötü prognostik özellikler gösterir (11). Evre, tümörün büyüklüğü, ileri yaş ve $B$ semptomlarının varlığı da hastalığın seyrinde önemli rol oynar $(1,2,12)$. Literatüre baktığımızda LFKHL'da Kì tutulumu sık iken, MSKHL'da \%10, NSKHL'da ise \%3 olarak görülmektedir (1). Shimabukuro-Vornhagen ve ark yaptığı çalışmada da NSKHL'da KI tutulumu \%3 dolayında izlenmiştir (9). Bizim serimizde literatürden farklı olarak NSKHL'da \%8 dolayında bulundu.

NLPHL indolan seyirli ve genellikle erken evrede karşımıza çıkarken, $\% 20$ dolayında olgu ileri evrede tanı alabilir. KHL ise daha agresif özellikler gösterir $(1,9)$. Hastalığın yayılımına baktığımızda, bizim serimizde, NLPHL \%78 lokalize kalma eğilimi gösterirken, KHL'da bu oran \%58 dolayında bulundu ve aradaki fark istatistiksel olarak da anlamlıydı $(p=0,039)$. Bizim serimizde NLPHL'nın \%16 dolayında yaygın hastalık oluşturduğu dikkatimizi çekti. KHL, NOS yanı sıra daha kötü prognostik özellikleri bilinen, LFKHL ve MSKHL gruplarında bölgesel ve yaygın hastalık oluşumu diğer gruplara göre belirgindi.

Tüm HL olgularımızın 1, 5, 10, 15 ve 20 yıllık genel sağ kalım oranları sırasıyla \%92, \%81, $\% 70, \% 62$ ve $\% 55$ dolayındadır. Bazzeh ve ark yaptığı çalışmada 5,10 ve 15 yıllık sağ kalım oranları sırasıyla $\% 80, \% 73$ ve $\% 67$ olarak bildirilmiştir (11). NLPHL'da sağ kalım KHL'ya göre daha uzun olmakla birlikte, aradaki fark istatistiksel olarak anlamlı saptanmadı. Gerber ve ark yaptığı çalışmada KHL'da 5,10 ve 15 yıllık sağ kalım sırasıyla \%81, \%74 ve \%69 dolayında bulunmuş (8); bizim serimizde $\% 81, \% 71$ ve $\% 62$ dolayında olup, yaklaşık benzer oranlar dikkati çekmiştir. Memiş ve ark yaptığı çalışmada da 5 ve 10 -yıllık sağ kalım oranları $\% 80,4$ ve $\% 72,9$ olarak bildirilmiştir (13). Histolojik alt tip ve EBV ile prognoz arasında bir ilişki saptanmaz iken, HL'da erkeklerde kadınlara göre sağ kalımın 
daha kısa olduğu dikkatimizi çekti $(p=0,006)$. Bazzeh ve ark yaptığı çalışmada da erkeklerde sağ kalım kadınlara göre daha kısa ve istatistiksel olarak anlamlı idi (11). Alt tiplere baktığımızda da benzer şekilde NSKHL ve KHL'da erkeklerde sağ kalım daha kısa idi $(p=0,001, p=0,003)$. Literatüre benzer olarak, NLPHL olgularımızda cinsiyet ve sağ kalım arasında bir fark saptanmadı (12). Ki lokalizasyonundan tanı alan olguların tamamı $\mathrm{KHL}$ grubunda olup, nodal ve ekstranodal lokalizasyondan tanı alan olgularla kıyaslandığında genel sağ kalımın belirgin olarak daha kısa olduğu ve istatistiksel olarak da anlamlı olduğu saptandı $(p<0,0001)$. Ancak diğer lokalizasyonlar arasında bir fark bulunmadı.

Yapılan çalışmalar göstermiştir ki; uygulanan tedavi rejimi, hastalığın evresi, ileri yaş ve tümörün yaygınlığı sağ kalım oranlarını etkilemektedir $(1-3,11)$. Bizim olgularımızda da Kİ tutulumu olanlarda, olmayanlara göre sağ kalımın daha kısa olduğu ve istatistiksel olarak da anlamlı olduğu görüldü $(p<0,0001)$. Hastalığın yaygınlığını değerlendirdiğimizde lokalize olan grupta sağ kalım en iyi iken, bölgesel ve yaygın hastalık oluşturan gruplara gidildikçe sağ kalımın kısaldığı dikkatimizi çekti $(p<0,0001)$. KHL'da tedavideki ilerlemeler ile 5-yıllık sağ kalım oranları \%90'ların üzerine çıkmıştır $(1,3,26)$. Çalışmamızda da beklenildiği gibi tedavi alanlarda sağ kalım, almayanlara göre daha uzun idi ve istatistiksel olarak da anlamlı bulundu $(p<0,0001)$. Tedavi rejimlerine baktığımızda, medyan sağ kalım KT almayanlarda 166 ay, alanlarda 302 ay olup, istatistiksel olarak aradaki fark anlamlı idi $(p<0,0001)$. Tedavi rejimleri yıllar içerisinde bazı değişimler göstermiş, RT eskiden daha çok tercih edilirken, günümüzde geri planda kalmıştır $(3,11)$. Bizim olgularımızın da \%11,4'üne RT uygulandı. RT alanlarda sağ kalım almayanlara göre daha iyi olmakla birlikte, istatistiksel anlamlılık saptanmadı $(p=0,246)$.
Ancak bazı çalışmalarda RT uygulananlarda sağ kalımın daha iyi olduğu vurgulanmaktadır $(8,11)$.

HL sıklığı ve mortalite oranları tüm dünyada değişkenlik göstermektedir. Bu nedenle toplumumuzda HL'ya ait epidemiyolojik ve sağ kalım özelliklerinin anlaşılması, global verilerle karşılaştırılarak tarama ve tedavi protokollerinin oluşturulabilmesi ve ulusal hastalık stratejisi belirlenebilmesi açısından önem taşımaktadır.

\section{Sonuç}

Sonuç olarak, EUKAM tarafından kaydedilmiş, 25 yıllık veri analiz bulgularımıza göre $\mathrm{HL}$, en sık görülen ikinci lenfoma tipi olup, erkeklerde kadınlara göre daha sık karşımıza çıkmaktadır. NSKHL en sık görülen KHL alt tipi olmakla birlikte, gelişmiş ülkelere göre biraz daha az görüldüğü, MSKHL ve LFKHL alt tiplerinin ise daha ön plana çıktığı dikkatimizi çekmektedir. Ayrıca EBV görülme oranları, gelişmiş ülkelere kıyaslandığında daha fazla olup, Asya ve Latin Amerika'ya göre de daha düşük olduğu görülmektedir. Sağ kalım bulgularımızın literatüre benzer olduğu görülmüştür. Ayrıca, erkeklerde kadınlara göre, KI tutulumu olanlarda olmayanlara göre ve yaygın hastalığı olanlarda lokalize olanlara göre sağ kalım daha kısa bulunmuştur. Prognozda, cinsiyet ve evre bizim çalışmamızda da öne çıkan önemli parametrelerdendir.

Çıkar çatışması: Yazarlar çıkar çatışması beyan etmemişlerdir.

Teşekkür: Bu çalışma 25 yıllık uzun bir dönemi kapsamaktadır. Bu süreçte emekleri geçen tüm Ege Üniversitesi Hematoloji Bilim Dalı öğretim üyeleri ve olguların tanı sürecinde eğitimimize sonsuz katkılarından dolayı hocamız Prof. Dr. Saliha Soydan'a, EÜKAM yetkilisi Ömer Karaca başta olmak üzere tüm kanser kayıt elemanlarına teşekkür ederiz.

\section{Kaynaklar}

1. Swerdlow SH, Campo E, Harris NL, et al. WHO classification of tumours of haematopoietic and lymphoid tissues, 4th edition (IARC WHO Classification of Tumours, Volume 2). International agency for research on Cancer (IARC). Lyon, 2017:423442.

2. Glaser SL, Jarrett RF. The epidemiology of Hodgkin's disease. Baillieres Clin Haematol 1996;9(3):401-16.

3. Ansell SM. Hodgkin lymphoma: 2018 update on diagnosis, risk-stratification, and management. Am J Hematol 2018;93:704-15.

4. Alexander FE, Jarrett RF, Lawrence D, et al. Risk factors for Hodgkin's disease by Epstein-Barr virus (EBV) status: prior infection by EBV and other agents. Br J Cancer 2000;82(5):1117-21.

5. Siegel RL, Miller KD, Jemal A. Cancer statistics, 2018. CA Cancer J Clin 2018;68(1):7-30.

6. Shanbhag S, Ambinder R. Hodgkin lymphoma: a review and update on recent progres. CA Cancer J Clin 2019;68(2):116-32. 
7. Jaffe ES, Arber DA, Campo E, Harris NL, Quintanilla FL, Orazi A. Hematopathology. 2nd ed. Philadelphia, PA: Elsevier Ltd; 2016:507-45.

8. Gerber NK, Atoria CL, Elkin EB, Yahalom J. Characteristics and Outcomes of Patients With Nodular LymphocytePredominant Hodgkin Lymphoma Versus Those With Classical Hodgkin Lymphoma: A Population-Based Analysis. Int J Radiat Oncol Biol Phys 2015;92(1):76-83.

9. Shimabukuro-Vornhagen A, Haverkamp H, Engert A, et al. Lymphocyte-Rich Classical Hodgkin's Lymphoma: Clinical Presentation and Treatment Outcome in 100 Patients Treated Within German Hodgkin's Study Group Trials. J Clin Oncol 2005;23(24):5739-45.

10. Gobbi PG, Ferreri AJM, Ponzoni M, Levis A. Hodgkin lymphoma. Crit Rev Oncol Hematol 2013;85(2):216-37.

11. Bazzeh F, Rihani R, Howard S, Sultan I. Comparing adult and pediatric Hodgkin lymphoma in the Surveillance, Epidemiology and End Results Program, 1988 - 2005: an analysis of 21734 cases. Leuk Lymphoma 2010;51(12):2198-207.

12. Pauw D. Nodular lymphocyte predominant Hodgkin lymphoma in USA between 2000 and 2014: an updated analysis based on the SEER data. Br J Haematol 2018;182:712-42.

13. Memiş Y, Kandaz M, Serdar L, Canyilmaz E. Hodgkin lenfomalı hastaların klinik özellikleri ve tedavi sonuçlarının geriye dönük analizi: Tek merkez deneyimi. Turk Onkoloji Dergisi 2015;30(1):16-20.

14. Belkaid MI, Zerhouni F, Beljord K, et al. Association of Epstein-Barr virus and Hodgkin's disease: comparison between Algerian and French patients. Bull Cancer. 1995;82(5):357-63.

15. Weiss LM, Chen Y, Liu X, Shibata D. Epstein-Barr Virus and Hodgkin's Disease. A correlative in situ hybridization and polymerase chain reaction study. Am J Pathol 1991;139(6):1259-65.

16. Zhou XG, Hamilton-Dutoit SJ, Yan QH, Pallesen G. The association between Epstein-Barr virus and Chinese Hodgkin's disease. Int J Cancer. 1993;55(3):359-63.

17. Park CS, Juhng SW, Brigati DJ, Montone KT. Analysis of Epstein-Barr virus in Hodgkin's disease: Experience of a single university hospital in Korea. J Clin Lab Anal 1994;8(6):412-7.

18. Chan JK, Yip TT, Tsang WY, Lau WH, Wong CS, Ma VW. Detection of Epstein-Barr virus in Hodgkin's disease occurring in an oriental population. Hum Pathol 1995;26(3):314-8.

19. Chang KL, Albújar PF, Chen YY, Johnson RM, Weiss LM. High prevalence of Epstein-Barr virus in the Reed-Sternberg cells of Hodgkin's disease occurring in Peru. Blood 1993;81(2):496-501.

20. Gulley ML, Eagan PA, Quintanilla-Martinez L, et al. Epstein-Barr virus DNA is abundant and monoclonal in the ReedSternberg cells of Hodgkin's disease: association with mixed cellularity subtype and Hispanic American ethnicity. Blood 1994;83(6):1595-602.

21. Quintanilla-Martínez L, Gamboa-Domínguez A, Gámez-Ledesma I, Orozco-Estevez H, Angeles-Angeles A. High prevalence of the Epstein-Barr virus in a Mexican population with Hodgkin's disease. Rev Invest Clin 1994;46(5):355-62.

22. Yang M, Ping L, Liu W, et al. Clinical characteristics and prognostic factors of primary extranodal classical Hodgkin lymphoma: a retrospective study. Hematology 2019;24(1);413-19.

23. Ma J, Wang $\mathrm{Y}$, Zhao $\mathrm{H}$, et al. Clinical characteristics of 26 patients with primary extranodal Hodgkin lymphoma. Int $\mathrm{J}$ Clin Exp Pathol 2014;7(8):5045-50.

24. Men Y, Sun X, Wei D, Yu Z. Primary extranodal head and neck classical Hodgkin lymphoma: A rare clinical case report. Exp Ther Med 2016;12(2):1007-11.

25. Laurent $C$, Arber DA, Johnston $P$, Fend F, Zamo A, Attygalle AD. Diagnosis of classic Hodgkin lymphoma on bone marrow biopsy. Histopathology 2020;76(7):934-41.

26. Connors JM. Hodgkin's Lymphoma — The Great Teacher. N Engl J Med 2011;365(3):264-5. 